\title{
Measurement of genetic damage in Apis mellifera caused by agrochemicals using comet assay
}

\author{
Silvia Villar ${ }^{1,2,3, *}$ and Pilar Ojeda ${ }^{4}$ \\ ${ }^{1}$ Instituto Iberoamericano de Estudios de Postgrados (IBEP); ${ }^{2}$ Agencia Nacional de Investigación e \\ Innovación (ANII); ${ }^{3}$ Administración Nacional de Educación Pública (ANEP), Montevideo; \\ ${ }^{4}$ Departamento de Ambiente, Comisión Administradora del Río Uruguay (CARU), Paysandú, Uruguay.
}

\begin{abstract}
In modern agriculture, synthetic agrochemicals are still the main line of defense in most pest management programs. Insecticides can have lethal or sublethal impacts on non-target organisms (species that recycle nutrients in the soil, pollinators and predators of target species). They also can contaminate food sources of organisms of higher trophic levels. To achieve protection of non-target organisms from the effects caused by the continued development and use of agrochemicals in modern agriculture, the European Economic Community and the Environmental Pollutant Agency emphasize the necessity of developing bioassays on honeybees to approve an agrochemical registration. The toxicity of commercial formulations of two insecticides, $\alpha$-endosulphan (organochlorine) and $\alpha$-cypermethrin (piretroid), and a commercial formulation of the herbicide glyphosate (organophosphorus) was analyzed. The analysis was performed on the bees using the comet assay as a biomarker of damaged DNA. The assay performed demonstrated the mutagenic effects caused by agrochemicals in DNA cells of the hypopharingeal gland from the bees.
\end{abstract}

KEYWORDS: Apis mellifera, comet assay, agrochemicals, mutagenic, $\alpha$-endosulphan, $\alpha$-cypermethrin glyphosate.

\footnotetext{
*Corresponding author: environscience21@gmail.com
}

\section{INTRODUCTION}

In modern agriculture, synthetic agrochemicals are still the main line of defense in most pest management programs. Insecticides can have lethal or sublethal impacts on non-target organisms (species that recycle nutrients in the soil, pollinators and predators of target species). They also can contaminate food sources of organisms of higher trophic levels [1]. Global production of agrochemicals has been increasing over the past decades [2]. These chemicals along with land management practices have been identified as key pressures on pollinators. Numerous studies have demonstrated the negative impact of agrochemicals on Apis mellifera bees [2].

To achieve protection of non-target organisms from the effects caused by the continued development and use of agrochemicals in modern agriculture, the EEC (European Economic Community) and the U.S. EPA (Environmental Pollutant Agency of the United States) emphasize the importance of the bioassays data on honeybees to approve any agrochemical registration. [3]. These products are classified as non-toxic, moderately toxic or highly toxic according to the results obtained in acute toxicity tests performed in vitro $[4,5]$. However, there are a number of disadvantages of the acute toxicity tests that often are not considered; one of the most important disadvantages is the exposure of the species to sublethal concentrations of compounds commonly used in crop protection and in the measurements of these effects [6-9]. 
A wide variety of behavioral and physiological sublethal effects of agrochemicals, especially insecticides have been reported in bee exposure assays. These effects range from effects on odor discrimination to loss of foraging bees due to a behavior alteration in the guidance system that allows the bees to return to the beehive [10].

The single cell gel electrophoresis or comet assay is a technique through which each individual comet is scored to give a measure of the DNA damage [11]. Nowadays, this genetic biomarker is widely used in genetic toxicology due to the fact that it is a high-throughput screening assay $[11,12]$.

Under alkaline conditions this assay detects DNA strand breaks and alkali labile sites by measuring the migration of DNA from immobilized nuclear DNA [13]. It combines the simplicity of biochemical techniques for detecting DNA single strand breaks (strand breaks and incomplete excision repair sites), alkali labile sites and cross-linking [14]. The main advantages of the comet assay include: (a) the collection of data at the level of the individual cell, allowing more robust statistical analyses, (b) the need for a small number of cells per sample $(<10,000)$, (c) sensitivity for detecting DNA damage and (d) use of any eukaryote single cell population both in vitro and in vivo, including cells obtained from exposed human populations and aquatic organisms, in environmental monitoring $[14,15]$.

The aim of this work is study the genotoxic effects of cypermethrin, endosulphan and glyphosate on hypopharyngeal cells of Apis mellifera individuals through comet assay.

\section{MATERIALS AND METHODS}

The honeybees used in the bioassays were newborn bees (age 1-7 d), obtained from hives using meshes to obtain the animals. The beehives were not treated with any kind of agrochemical. Bees were obtained from private beekeepers located in the southwest of Uruguay (Departamento de Colonia). The toxicity of commercial formulations of two insecticides, $\alpha$-endosulphan (organochlorine) and $\alpha$-cypermethrin (piretroid), and a commercial formulation of the herbicide glyphosate (organophosphorus) was analyzed.
The exposure assay was performed under temperature, humidity and light-controlled conditions for 48 hours. Ten bees from the hives were randomly selected and put in Petri dishes $\left(10 \mathrm{~cm}^{3}\right)$ for each agrochemical tested (ten per dish). All insecticides were diluted in acetone and the herbicide was diluted in water. Five concentrations were tested for each agrochemical. Five $\mu \mathrm{l}$ of each solution was applied to the thorax of the honeybees using a micropipette. For grouping and dose administration the honeybees were anesthetized using CO2 (g) [16]. Each group of 10 honeybees was kept in the Petri dishes containing a clean filter and a feeder with $1 \mathrm{ml}$ of sucrose $50 \% \mathrm{w} / \mathrm{v}$ for ad libitum consumption. Each assay was done in triplicate. The same procedure was performed using only the solvent recommended by EPA (acetone or water) as negative control.

The single cell gel electrophoresis was performed in cell samples obtained from the exposed bees after 48 hours following [17] with modifications. Hypopharyngeal glands were dissected in phosphate buffered saline solution under stereoscopic microscope Olympus $\mathrm{SZ} 40^{\mathrm{TM}}$. After trypsinization (0.25\% Trypsin-EDTA solution) (Sigma, U.K.), for $1.5 \mathrm{~h}$ at $37^{\circ} \mathrm{C}$, samples were centrifuged and trypsin was replaced by $75 \mu \mathrm{l}$ of the phosphate buffered saline solution. This tissue preparation provided whole and single cells. The cell suspension $(75 \mu \mathrm{l})$ and low melting agarose $(1 / 100)$ at $37^{\circ} \mathrm{C}$ was added to slides covered with $0.5 \%$ normal melting agarose. A coverslip was placed over the mixture. After solidifying, the coverslip was removed and the slides were gently immersed in lysing buffer $(\mathrm{pH} 10)$. Shortly after lysis, the slides were placed in a horizontal electrophoresis chamber containing ice-cold electrophoresis buffer, $\mathrm{pH}$ 13. Electrophoresis was run at $20 \mathrm{~V}$, $80 \mathrm{~mA}$ for $25 \mathrm{~min}$ at $10-14{ }^{\circ} \mathrm{C}$. Slides were stained with propidium iodide (PI) $(10 \mu \mathrm{g} / \mathrm{mL})$ and analyzed under a fluorescence microscope (Shiner XY-FLTM). To assess cytotoxicity one slide was removed from lysis after 1 hour and neutralized. Air-dried and stained slides were analyzed (100 cells per slides were scored). Cells were classified as normal cells when they showed condensed DNA with little diffusion and apoptotic cells when their DNA were visualized as diffused and condensed without the round normal shape. Samples exhibiting lower than $15 \%$ of apoptosis 
were used for the study. he parameters measured were the \% of DNA in the tail of the comet and the Olive tail moment (OTM) [18], measured by the Comet Score ${ }^{\mathrm{TM}}$ software.

Data normality and homoscedasticity obtained using biomarkers of genetic damage (\% of damaged DNA and OTM) were tested by Kolmogorov-Smirnov (normality) and Levene and Tukey (homoscedasticity) [19]. To compare the variables data, analysis of variance (ANOVA) for parametric data was developed at $\mathrm{p}<0.05$. All statistical analyses were performed using Statgraphic Centurion XVI.I ${ }^{\mathrm{TM}}$ software.
The doses assayed for each agrochemical solution were: $\alpha$-endosulphan $0.11,0.22,0.44,0.88$, $1.75 \mu \mathrm{g} / \mathrm{mL}$ and control solvent (acetone); $\alpha$ cypermethrin 0.016, 0.03, 0.06, 0.12 and $0.24 \mu \mathrm{g} / \mathrm{mL}$ and control solvent (acetone) and glyphosate 0.0125, 0.025, 0.05, 0.1, $0.5 \mu \mathrm{g} / \mathrm{mL}$ and control solvent (water).

\section{RESULTS}

Table 1 shows the average values of all replicates for each dose obtained in the comet assay. The ANOVA test showed significant differences at

Table 1. Genetic damage obtained through the comet assay for three agrochemical compounds. *means not significant with respect to the control solvent.

\begin{tabular}{|c|c|c|}
\hline $\begin{array}{c}\text { Agrochemicals } \\
\text { (grey rows)/Doses }(\mu \mathrm{g} / \mathrm{mL})\end{array}$ & $\%$ of DNA damage & OTM \\
\hline \multicolumn{3}{|l|}{ a-endosulphan } \\
\hline 0.11 & 5.1 & 3.9 \\
\hline 0.22 & 9.0 & 4.4 \\
\hline 0.44 & 11.1 & 6.2 \\
\hline 0.88 & 13.1 & 8.9 \\
\hline 1.75 & 16.6 & 10.9 \\
\hline Average value & 11.0 & 6.9 \\
\hline Control solvent & 4.4 & 2.2 \\
\hline \multicolumn{3}{|l|}{ a-cypermethrin } \\
\hline 0.016 & $3.6 *$ & $2.1 *$ \\
\hline 0.03 & 7.5 & 5.0 \\
\hline 0.06 & 11.5 & 7.7 \\
\hline 0.12 & 14.6 & 7.9 \\
\hline 0.24 & 17.4 & 8.1 \\
\hline Average value & 10.9 & 6.1 \\
\hline Control solvent & 3.3 & 2.5 \\
\hline \multicolumn{3}{|l|}{ Glyphosate } \\
\hline 0.0125 & 6.1 & 3.5 \\
\hline 0.025 & 7.3 & 5.3 \\
\hline 0.05 & 10.7 & 7.4 \\
\hline 0.1 & 16.6 & 9.2 \\
\hline 0.5 & 18.2 & 13.7 \\
\hline Average value & 11.8 & 7.8 \\
\hline Control solvent & 0.5 & 0.4 \\
\hline
\end{tabular}


$\mathrm{p}<0.05$ for samples exposed to $\alpha$-endosulphan between all doses analyzed and compared to the control solvent; both for \% of DNA damage and OTM. The same situation was registered for samples exposed to $\alpha$-cypermethrin except for the $0.016 \mu \mathrm{g} / \mathrm{mL}(\mathrm{p}<0.07)$ dose at $\mathrm{p}<0.05$. The samples exposed to glyphosate showed significant differences for all doses and with respect to the control solvent for both variables. The highest values of genetic damage were observed in the glyphosate assay, showing a maximum level of $18.2 \%$ of DNA damage and 7.8 for OTM; however the averaged values were similar for all the agrochemicals tested. All doses assayed for the agrochemicals tested provoked genetic damage at sublethal levels for both variables analyzed (Figures 1, 2).

\section{DISCUSSION}

Bees are the most common pollinators of many wild and monoculture plants [20]. Therefore, their niche is essential for productivity in agriculture and it is clear that the alterations in their populations could lead to significant economical

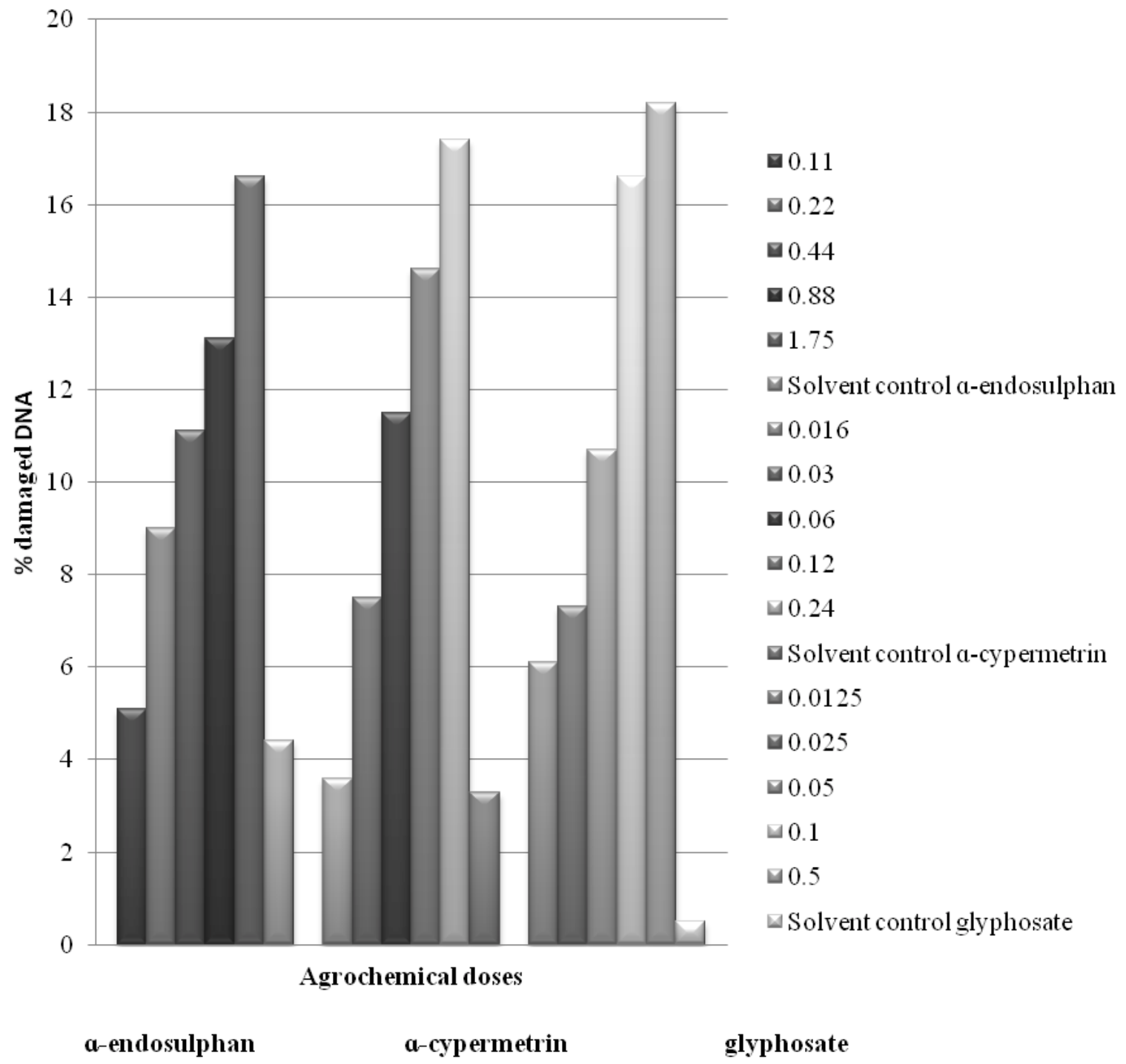

Figure 1. Percentage of DNA damage in cells obtained from the hypopharingeal gland of honey bees after exposure to increasing doses of insecticides and a herbicide. 


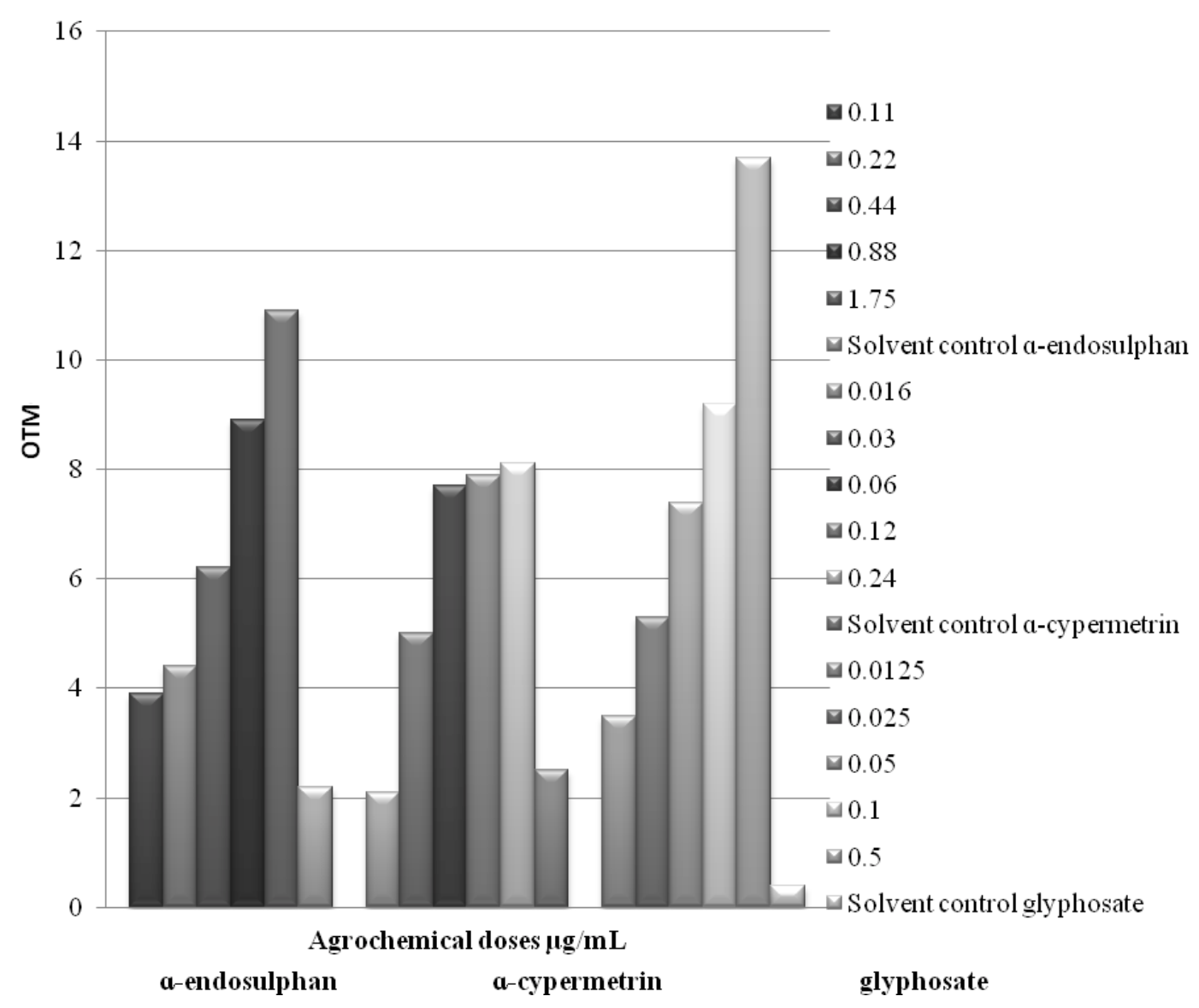

Figure 2. OTM values of DNA cells obtained from the hypopharingeal gland of honey bees after exposure to increasing doses of insecticides and a herbicide.

losses [21, 22]. The current situation of bees is critical, because according to population census around the world they have drastically decreased owing to the extensive use of agrochemicals in monocultures in order to enhance the production yield [23-25].

In general, for arthropods, pesticides induce physiological alterations at the social level, reflected by changes in behavior, and difficulties in locating the food, communication and localization of the niches where they live [26].

In most developed countries endosulphan is prohibited; however, in some developing countries it is still commonly used [27]. In Uruguay, the use of endosulphan was restricted to a single annual application by the Ministry of Agriculture and Fisheries (MGAP in Spanish, 2007) and in 2011 (ordinance 104/011) its use was prohibited but the authorities' control on its use and sale is not totally effective [28, 29]. Organochlorine insecticides interfere with the chlorine channels in the nerve cell membrane, blocking the transmission of nerve impulses. Organochlorine insecticides are capable of persisting in the environment for a long time and they are accumulated in the organisms. Intake of organochlorine insecticides and their accumulation may increase their concentrations, geometrically, depending on what level in the trophic chain a species is located. They may cause chronic poisoning even if they are in low doses [30].

Organic phosphoric compounds are cholinesterase inhibitors. Organophosphates block the action of this enzyme which interrupts the transmission of nerve impulses; they show similar toxicity levels in vertebrate and invertebrate organisms even at low concentrations (ng- $\mu \mathrm{g} / \mathrm{mL})[5,6,7,30]$.

The repellent nature of pyrethroids makes it important to limit the exposure of bees to this 
group of highly toxic insecticides. They are neurotoxic, disturbing the normal functioning of the nervous system of insects, and exert their toxic effects primarily affecting the conduction properties of the sodium channels, which are essential for the generation and propagation of the action potentials of excitable cells [8, 25]. Some authors [8, 31] found that pyrethroids significantly suppress neuronal excitability in brain cells of honey bees and sodium channels of the nerve membrane.

Pollutant pesticides in floral resources affect the critical learning process of orientation and recognition of the environment in bees [8, 26, 32]. It occurs because the pesticides reach the main neural pathways of bees and disrupt processes of learning, memory, navigation and certain cognitive functions $[8,33]$.

\section{CONCLUSION}

The aassay performed demonstrated the mutagenic effects caused by agrochemicals in DNA cells of the hypopharingeal gland from bees; however the action was tested over a short period of time (hours). Chronic exposure to the pesticides could have additional effects and may affect the general performance of the entire colony. We don't know how efficient the DNA-repairing process in gland cells is; however, the chronic exposure to agrochemicals can affect the DNA-repairing process through saturation of the DNA-repairing machinery; if the DNA repairing significantly increases, the chances of errors occurring during this process also increase. The accumulation of genetic damage can provoke cell death, apoptosis or miss-repaired mutations, affecting the normal physiological process of the organisms.

\section{CONFLICT OF INTEREST STATEMENT}

There is no conflict of interest.

\section{REFERENCES}

1. Devine, G. and Furlong, M. 2007, Agriculture and Human Values, 24, 281.

2. Brittain, C. and Potts, S. 2011, Basic and Applied Ecology, 12, 321.

3. Devillers, J., Pham-Delegue, M., Decourtye, A., Budzinski, H., Cluzeau, S. and Maurin, G. 2003, Bulletin of Insectology, 56, 103.
4. Cluzeau, S. 2002, Honey Bees: Estimating the Environmental Impact of Chemicals, J. Devillers and M. Pham-Delegue (Ed.), Taylor and Francis, London, UK.

5. Rortais, A., Arnold, G., Halm, M. and Touffet-Briens, F. 2005, Apidologie, 36, 71.

6. Decourtye, A., Devillers, J., Cluzeau, S., Charreton, M. and Pham-Delègue, M. 2004, Ecotoxicology and Environmental Safety, 57, 410.

7. Decourtye, A., Devillers, J, Genecque, E., Le Menach, K., Budzinski, H., Cluzeau, S. and Pham-Delègue, M. 2005, Archives of Environmental Contamination and Toxicology, 48, 242.

8. Yang, E., Chuang, Y., Chen, Y. and Chang, L. 2008, Journal of Economic Entomology, 101, 1743.

9. Wu, J., Anelli, C. and Sheppard, W. 2011, PLoS One, 6(2), e14720.

10. Thompson, H. and Wilkins, S. 2003, Bulletin of Insectology, 56, 131.

11. Azqueta, A. and Collins, A. 2013, Arch. Toxicol., 87, 949.

12. Tice, R., Aqurrel, E., Anderson, D., Burlinson, B., Hartmann, A., Kobayashi, H., Miyamae, Y., Rojas, E., Ryu, J. and Sasaki, Y. 2000, Environ. Mol. Mutagen., 35, 206.

13. De Lapuente, J., Lourenço, J., Mendo Sónia, A., Borràs, M., Martins, M., Costa, P. and Pacheco, M. 2015, Frontiers in Genetics, 6, 180.

14. Lee, R. and Steinert, S. 2003, Mutation Research, 544, 43.

15. Kumaravel, T., Vilhar, B., Faux, S. and Awadhesh, J. 2009, Cell Biology and Toxicology, 25, 53.

16. Tasei, J. N., Pham-Delegue, M-H. and Belzunces, L. 2003, Bulletin of Insectology, 56, 189.

17. de Moraes, S. and Bowen, I. 2000, Cell Biol. Int., 24, 737.

18. Singh, N., McCoy, M., Tice, R. and Schneider, E. 1988, Exp. Cell Res., 175, 184.

19. Zar, J. 2010, Biostatistical Analysis, Pearson Education, London.

20. Kremen, C., Williams, N. and Thorp, R. 2002, Proceedings of the National Academy of Sciences, 26, 16812.

21. Garibaldi, L. 2013, Science, 339, 1608. 
22. Cutler, C., Purdy, J., Giesy, J. and Solomon, K. 2014, Environmental Contamination and Toxicology, 231, 219.

23. Goulson, D., Nicholls, E., Botias, C. and Rotheray, E. L. 2015, Science, 347, 1255957.

24. Kovács-Hostyánski, A. 2017, Ecology Letters, 20, 673.

25. Martin-Culma, N. and Arenas-Suárez, N. 2018, Entramado, 14, 232.

26. Desneux, N., Decourtye, A. and Delpuech, J. 2007, Annual Review of Entomology, $52,81$.

27. Betancur, L., Ocampo, R. and Rìos, L. 2015, Luna Azul, 40, 1909.
28. Pizarro, V. 2014, La verdad de los plaguicidas en Uruguay.

29. Núñez, B. and Ferreira, T. 2017, Intoxicados. Brecha, 1636.

30. Figen Esin K., Kaymak, G. and Nazan Deniz, Y. 2013, Marmara Üniversitesi, 25, 167.

31. Zhou, T., Zhou, W., Wang, Q., Dai, P-L., Liu, F., Zhang, Y-L. and Sun, J-H. 2011, Pesticide Biochemistry and Physiology, 100, 35.

32. Andrione, M. 2016, Scientific Reports, 6, 38110.

33. Klein, S. 2017, Trends in Ecology and Evolution, 20, 1. 